\title{
EVALUATION OF FACTORS AFFECTING COLLECTION EFFICIENCY ESTIMATES OF CHINOOK SALMON AND STEELHEAD SMOLTS AT MCNARY DAM, 1989
}

\section{FINAL REPORT}

\author{
Prepared by: \\ Lowell Stuehrenberg \\ Douglas Smith \\ and \\ Orlay W. Johnson \\ Coastal Zone and Estuarine Studies Division \\ Northwest Fisheries Science Center \\ National Marine Fisheries Service \\ National Oceanic and Atmospheric Administration
}

Prepared for:

U.S. Department of Energy

Bonneville Power Administration

Environment, Fish and Wildlife

P. 0. Box 3621

Portland. OR 97208-362 I

Project Number XX- 134

Contract Number DE-A179-88BP9 1024

October 1995 
CONTENTS

Page

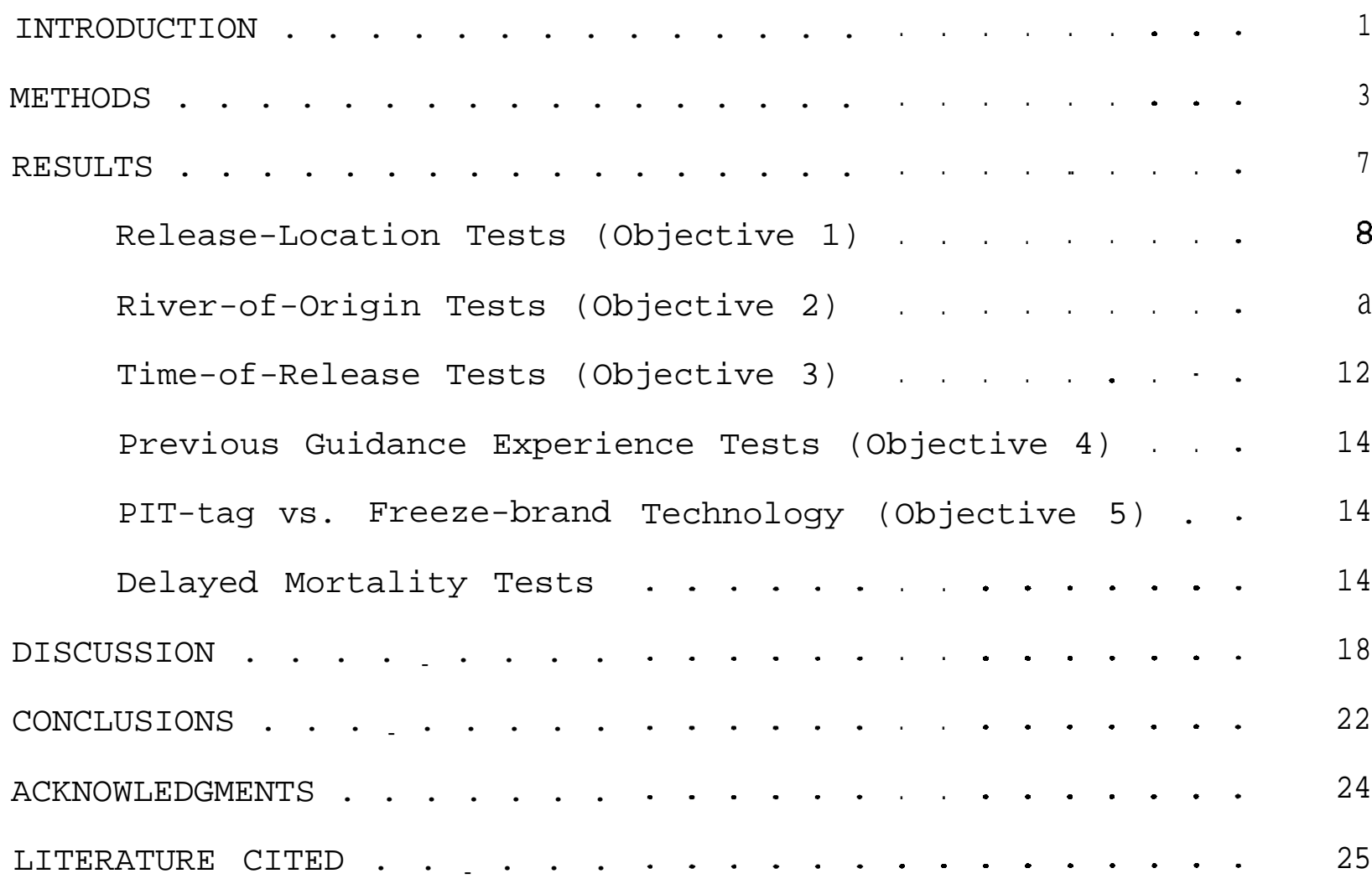




\section{INTRODUCTION}

Populations of salmonid smolts migrating through the hydropower system on the Columbia River incur some rate of mortality at each dam. To set priorities on options to minimize losses and provide safe passage of the smolts at dams, estimates of smolt survival at each dam are necessary. Two methods have been developed to obtain these survival estimates: the direct and the indirect method.

With the indirect method, a test group of fish is released upstream and a control group is released downstream from the area of interest. Both groups of fish are recovered at a single location downstream from the release sites. Valid assumptions required for an indirect test include: 1) that test and control groups are mixed between the control group release site and the recovery site (i.e. they have equal arrival time and location at the recovery site), and 2) that test and control groups incur the same release-to-recapture (release-to-detection for PIT tags) mortality rate. These assumptions may be invalid if the test group must travel a substantial distance before reaching the release site of the control group.

With the direct method, a single release of fish above the area of interest is used, with subsequent recovery below the area of interest. This method requires a knowledge of the collection rate of the recovery method and a knowledge of the mortality rate between the release and recapture (detection for PIT tags) sites. 
Lower Granite, Little Goose, and McNary Dams on the Snake and Columbia Rivers have juvenile bypass systems that can be used to recapture marked fish from upstream releases. The bypass systems at these dams divert salmonid migrants away from the turbines to a handling/transport facility. During periods of no spill, all juveniles pass into the turbine intakes, where some percentage of them are diverted by traveling screens into the juvenile bypass system. When spill occurs, juveniles pass through the spillway and powerhouse; thus, a lesser percentage of the total population arriving at the dam is diverted into the juvenile bypass system. Collection efficiency is defined as the proportion of the population passing the dam that enters the bypass system.

In 1982-83, Giorgi and Sims (1987) used the direct method with multiple groups of freeze-branded steelhead (Oncorhynchus mykiss) and chinook salmon (0. tshawytsha) to study the relationship between the portion of river flow passing through McNary Dam Powerhouse and the portion of marked groups recaptured in the McNary Dam bypass system. From their data, they developed linear relationships to estimate collection efficiency under varying flow conditions. Subsequent to their work, however, sources of variation associated with these linear relationships have been identified. These sources may account for the high variance in survival esti mates based upon their data.

In 1988, the National Marine Fisheries Service (NMFS) began a 2-year study at McNary Dam to address possible sources of 
variation associated with the direct method of obtaining survival estimates. Five study objectives were established to determine whether 1) fish from the Columbia and Snake Rivers mixed as they migrated to McNary Dam (release-location tests); 2) collection rates for Columbia and Snake River stocks were the same (riverof-origin tests); 3) test-group release timing influenced recovery rates (time-of-release tests); 4) a collection-rate bias existed from use of test fish previously guided and collected at the recovery site (tests of previously guided fish); and 5) recovery rates obtained with PIT-tagged fish were comparable to those previously obtained with freeze-branded fish (PIT-tag vs. freeze-brand technology).

\section{METHODS}

Fish handling and release methods varied depending upon the capture site and objective. Yearling chinook salmon and steelhead were captured for the study at Priest Rapids, Ice Harbor, and McNary Dams, and from the McNary reservoir near Port Kelly, Washington (River Kilometer [RKm] 499) (Fig. 1). Fish at Priest Rapids Dam (Columbia River fish) were obtained from the gatewells with a butterfly dip-net, tagged at the dam, and transported in 662-L tanks to Port Kelly. Fish at Ice Harbor Dam (Snake River fish) were obtained from the gatewells with a gatewell dip-basket, transported in 662-L tanks to Port Kelley, and accumulated in holding tanks until sufficient numbers were obtained for tagging (2 or 3 days). Fish at McNary Dam were 


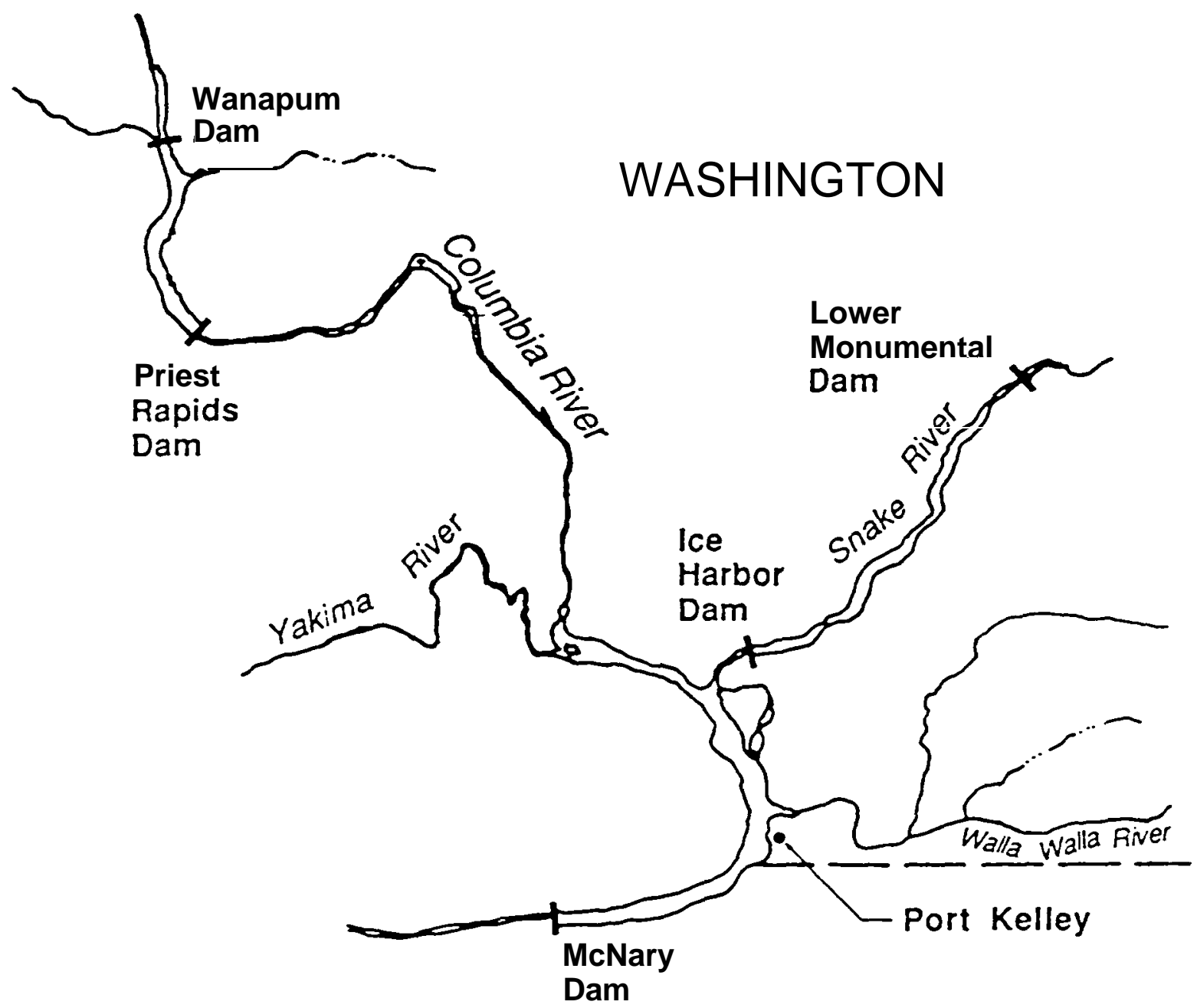

OREGON

Figure 1. --Study area for the 1989 collection efficiency study. 
obtained from the subsample taken at the juvenile collection facility, tagged at the dam, and transported in 662-L tanks to Port Kelly. McNary Reservoir fish were collected with a purse seine, transported in 662-L tanks to Port Kelley, and accumulated in holding tanks until sufficient numbers were obtained for tagging (2 or 3 days).

Preanesthetic and water-to-water transfer techniques were used at all collection, marking, and release sites in 1989 . Smolts were PIT tagged using the marking procedures and automatic tagging instrument described by Prentice et al. (1990). After tagging, all fish were held at Port Kelley in the transport tanks for 24 hours. Following recovery, mortalities were removed from the transport tanks and 100 fish from each group were placed into a holding area for a 96 hour delayed mortality test. The transport tanks (and fish) were then loaded onto a boat and taken to the release sites. Release locations for the study were $26 \mathrm{~km}$ upstream from McNary Dam (Columbia River RKm 499) and $91 \mathrm{~m}$ offshore from each shoreline (north and south shore).

The research design, developed in 1989, required three paired releases for each objective and each species. Based upon observed PIT-tag recoveries in 1988, we estimated that 400 to 600 tagged fish per release group would be required to obtain 200 detections at McNary Dam.

Three mixing tests were made with yearling chinook salmon and two with steelhead (Objective 1). For these tests, groups were released at either the north shore (spillway side) or south 
shore (turbine intake side) release sites mentioned above. Objective 2 (river-of-origin tests) used the same fish as Objective 1 with Snake and upper-Columbia River releases divided between north and south shore release sites. Each Objective 3 (time-of-release) test had one release at $1200 \mathrm{~h}$ and a second at $1900 \mathrm{~h}$, with both releases made from the north shore release site. Tests under Objective 4 (effects of previous guidance experience) compared groups collected from McNary Dam bypass system versus those collected in the McNary forebay, with both groups released from the north shore release site.

The detection site for the PIT-tagged fish was the McNary Dam PIT-tag monitoring system described by Prentice et al. (1990). All fish entering the juvenile bypass system at McNary Dam pass PIT-tag monitors, and detections are automatically recorded on an on-site computer. For error checking and data analysis, data were downloaded daily to a computer in seattle, Washington.

Differences between detection rates at McNary Dam were based on PIT-tag detection rates between paired release groups. Chisquare and analysis of variance (ANOVA) procedures were used to statistically assess differences. In each test, the null hypothesis was that detection rates of the paired groups are equal. During the Objective 1 tests, similar detection rates would rule out the possibility that fish released from the north shore (spillway side) were passing through spillways at a significantly higher rate than fish released from the south shore 
(turbine side). During the Objective 2 tests, similar detection rates would rule out the possibility that upper Columbia and Snake River fish have a preference for water from their river-oforigin, which would result in larger numbers of Columbia River fish passing the dam on the spill side of the river (lower detection rates) and Snake River fish passing the dam on the powerhouse side of the river (higher detection rates). In Objective 3 tests, similar detection rates would rule out the possibility that differences in arrival time at McNary Dam could change collection efficiency rates. Similar detection rates for the objective 4 test would rule out the possibility that collection efficiency can be affected by a learned behavior (in fish previously collected in the McNary Dam bypass system) . To compare results from this study (PIT tag) with results from previous studies using freeze-brand technology (Objective 5), a linear regression analysis was generated using PIT-tag and powerhouse-flow data from 1988 and 1989. This analysis was similar to the powerhouse flow-to-collection rate' relationship presented by Giorgi and Sims (1987).

RESULTS

Observed flows at McNary Dam during the 1989 study ranged from 136,000 to 377,000 cubic feet per second (kcfs) (3.8-10.6 thousand cubic meters per second [kcms]). During the chinook salmon tests, the daily average flow rate ranged from 188 to 315 kcfs (5.3-8.8 kcms), and varying levels of spill occurred during 
8

each replicate. Flows during the steelhead tests had a slight downward trend (range 232-194 kcfs [6.5-5.4 kcms]) and no spill occurred. A total of 9,597 chinook salmon and 8,752 steelhead smolts were tagged and released during the study.

\section{Release-Location Tests (Objective 1)}

McNary Dam detection rates for fish from five of the six chinook salmon release-location tests (Table 1) were not significantly different $(\mathrm{P}>0.05)$. However, detection rates from north and south shore released fish in the third test group were significantly different, with 43\% and 50\% detected from the north and south shore release sites, respectively $\left(X^{2}=6.007\right.$, $\mathrm{P}=0.014)$. For steelhead, no significant differences among replicates were observed between the four north and south shore release groups $(\mathrm{P}>0.05)$ (Table 2). Median travel time differences within replicates were notably similar.

\section{River-of-Origin Tests (Objective 2)}

There were three paired tests using Columbia River and Snake River chinook salmon. Analysis indicated significant differences (Table 3) between the detection rates of chinook salmon from the Columbia and Snake Rivers during the first two tests $(P<0.05)$. Ice Harbor Dam-collected (Snake River) smolts had a higher detection rate in the first test (68\% vs. 59\%) and a lower rate in the second test (46\% vs. 56\%). Priest Rapids Dam-collected (Columbia River) fish from the first replicate and Ice Harbor Dam-collected fish from the second replicate passed during higher 
Table 1.--Collection site, release site, test number, median release-to-detection travel time, number of chinook salmonreleased at Port Kelly, Washington, percent of the river flow passing through the powerhouse, proportion of the release recaptured at McNary Dam, and Chi-square level of significance (P) for tests to determine the effects of release location on McNary Dam detection rates (Objective 1 ).

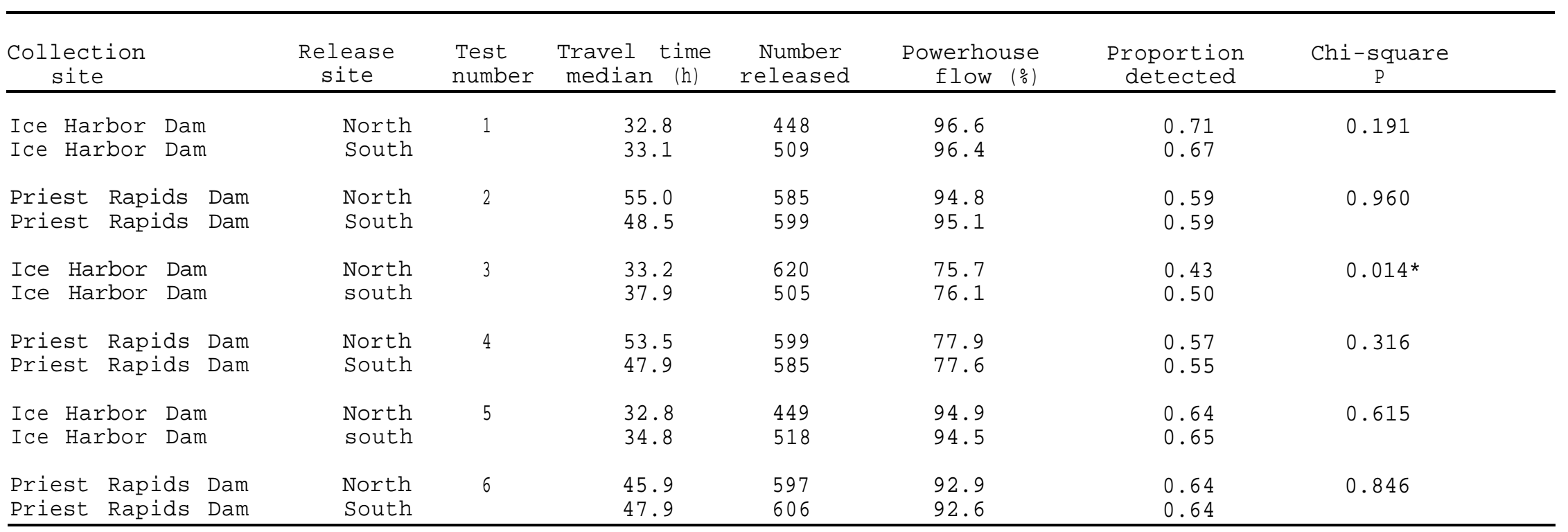

*Significant difference, $\mathrm{P}<0.05$. 
Table 2.--Collection site, release site, test number, median release-to-detection travel time number of steelhead released at Port Kelly, Washington, percent of the river flow passing through the powerhouse, proportion of the release recaptured at McNary Dam, and Chi-square level of significance (P) for tests to determine the effects of release location on McNary Dam detection rates (Objective 1).

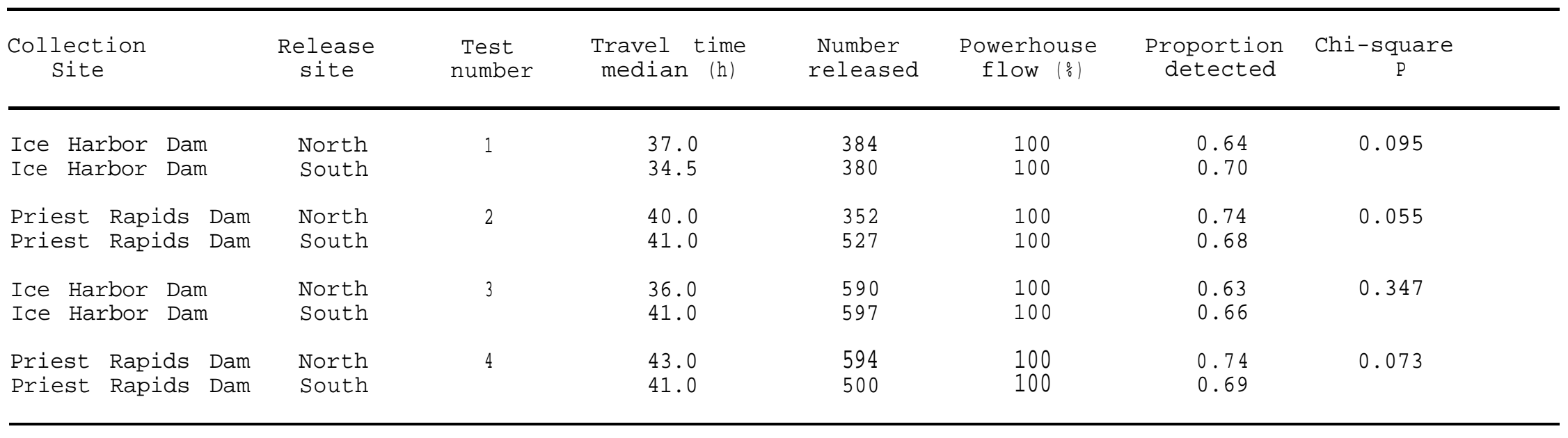


Table 3.--Collection site, test number, median release-to-detection travel time, number of chinook salmon or steelhead released at Port Kelly, Washington, percent of the river flow passing through the powerhouse, proportion of the release recaptured at McNary Dam, and Chi-square level of significance (P) for tests to determine the effects of river-of-origin on McNary Dam detection rates (Objective 2).

\begin{tabular}{cccccc}
\hline $\begin{array}{c}\text { Col lection } \\
\text { site }\end{array}$ & $\begin{array}{c}\text { Test } \\
\text { number }\end{array}$ & $\begin{array}{c}\text { Travel time } \\
\text { median }\end{array}$ & $\begin{array}{c}\text { Number } \\
\text { released }\end{array}$ & $\begin{array}{c}\text { Powerhouse } \\
\text { flow (\%) }\end{array}$ & $\begin{array}{c}\text { Proportion } \\
\text { detected }\end{array}$ \\
\hline
\end{tabular}

Ch inook salmon

\begin{tabular}{|c|c|c|c|c|c|c|}
\hline $\begin{array}{l}\text { Ice Harbor Dam } \\
\text { Priest Rapids Dam }\end{array}$ & 1 & $\begin{array}{l}33.0 \\
51.9\end{array}$ & $\begin{array}{r}95 \% \\
1184\end{array}$ & $\begin{array}{l}96.3 \\
94.9\end{array}$ & $\begin{array}{l}0.68 \\
0.59\end{array}$ & $0.000 *$ \\
\hline $\begin{array}{l}\text { Ice Harbor Dam } \\
\text { Priest Rapids Dam }\end{array}$ & 2 & $\begin{array}{l}35.5 \\
\mathbf{5 0 . 9}\end{array}$ & $\begin{array}{l}1125 \\
\mathbf{1 1 8 4}\end{array}$ & $\begin{array}{l}75.9 \\
71.8\end{array}$ & $\begin{array}{l}0.46 \\
\mathbf{0 . 5 6}\end{array}$ & $0.000 *$ \\
\hline $\begin{array}{l}\text { Ice Harbor Dam } \\
\text { Priest Rapids Dam }\end{array}$ & 3 & $\begin{array}{l}34.5 \\
47.1\end{array}$ & $\begin{array}{r}967 \\
1203\end{array}$ & $\begin{array}{l}94.7 \\
92.7\end{array}$ & $\begin{array}{l}0.64 \\
0.64\end{array}$ & 0.832 \\
\hline \multicolumn{7}{|c|}{ Steelhead } \\
\hline $\begin{array}{l}\text { Ice Harbor Dam } \\
\text { Priest Rapids Dam }\end{array}$ & 1 & $\begin{array}{l}\text { 36. } 0 \\
41.0\end{array}$ & $\begin{array}{l}764 \\
879\end{array}$ & $\begin{array}{l}\mathbf{1 0 0} \\
100\end{array}$ & $\begin{array}{l}\mathbf{0 . 6 7} \\
0.71\end{array}$ & 0.139 \\
\hline $\begin{array}{l}\text { Ice Harbor Dam } \\
\text { Priest Rapids Dam }\end{array}$ & 2 & $\begin{array}{l}\text { 38. } 0 \\
42.0\end{array}$ & $\begin{array}{l}1187 \\
1094\end{array}$ & $\begin{array}{l}100 \\
100\end{array}$ & $\begin{array}{l}0.65 \\
0.72\end{array}$ & 0. 000* \\
\hline $\begin{array}{l}\text { Ice Harbor Dam } \\
\text { Priest Rapids Dam }\end{array}$ & 3 & $\begin{array}{l}\mathbf{3 7 . 0} \\
41.0\end{array}$ & $\begin{array}{r}1067 \\
891\end{array}$ & $\begin{array}{l}100 \\
100\end{array}$ & $\begin{array}{l}0.46 \\
0.66\end{array}$ & 0. 000* \\
\hline
\end{tabular}

*Significant difference, $P<0.05$. 
spill rates, and both were detected at significantly lower proportions than their cohorts. Median travel time differences within replicates were markedly different.

Detection rates from the first steelhead river-of-origin test were not different while those from Test 2 and Test 3 were significantly different: $X^{2}=12.69, P=0.000 ;$ and $X^{2}=81.22$, $\mathrm{P}=0.000$ for Tests 2 and 3 , respectively (Table 3). The detection rates for Ice Harbor Dam-collected steelhead were lower in the same two tests: 65\% vs. 72\% for Test 2 and $46 \%$ vs. 66\% for Test 3. Median travel time differences within replicates were notably similar.

\section{Time-of-Release Tests (Objective 3)}

Based upon the low probability of spill occurring during the third steelhead replicate, the study design was changed to evaluate the effects of diel release times on McNary Dam collection efficiency rates. Release groups were obtained from Ice Harbor, Priest Rapids, and McNary Dams (Table 4). Detection rates for steelhead collected at Ice Harbor and McNary Dams (Tests 1 and 3) and released at noon or evening were significantly different $\left(X^{2}=27.31, P=0.000\right.$, and $X^{2}=6.944, P$ $=0.008$, respectively). For steelhead collected at Priest Rapids Dam (Test 2) detection rates for noon and evening releases were not significantly different $(\mathrm{P}>\mathbf{0 . 0 5})$. Median release-todetection travel times for these replicates were similar. However, the effect of different release times would cause the fish to arrive at the dam at different times of the day. 
Table 4.--Collection site, test number, hour released, median release-to-detection time, number of steelhead released at Port Kelly, Washington, percent of the river flow passing through the powerhouse, proportion of the release recaptured at McNary Dam, and Chi-square level of significance (P) for test to determine the effect of time-of-release on McNary Dam detection rates (objective 3 ).

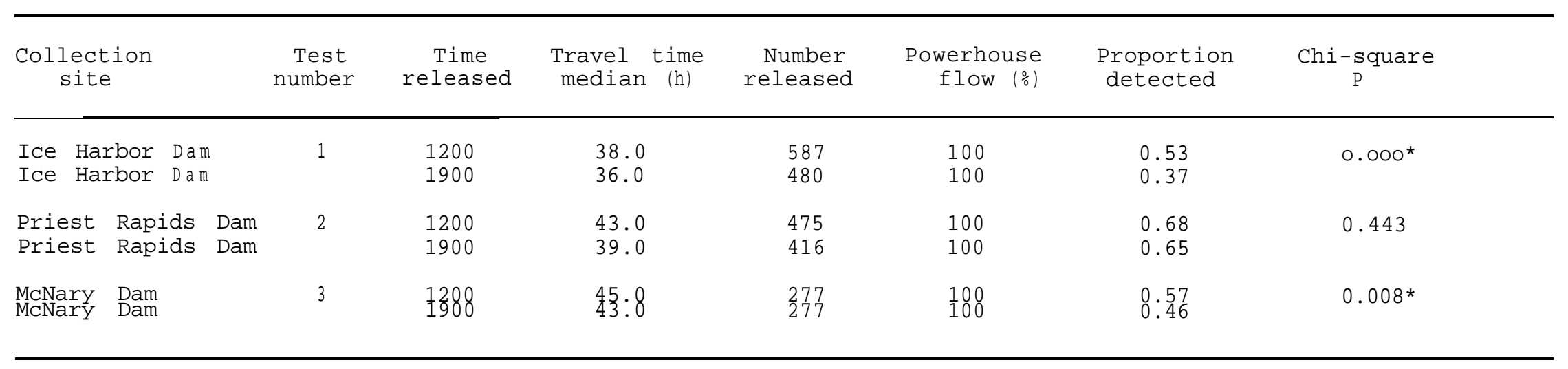

*Significant difference, $\mathrm{P}<0.05$. 


\section{Previous Guidance Experience Tests (Objective 4)}

Detection rates for previously guided chinook salmon were consistently higher than those for inexperienced fish (Table 5). However, Chi-square analysis of the collection rates suggested no significant difference between previously guided and inexperienced fish $(P>0.05)$ in two of the three test groups. Significant differences were detected for the third test $\left(X^{i}=8.121, P=0.004\right)$. For steelhead, previously guided fish were invariably detected at higher rates than inexperienced fish $\left(X^{2}=8.347, P=0.004 ;\right.$ and $X^{2}=49.51, P=0.000$, respectively $)$. Within replicate median release-to-detection travel times were notably similar.

\section{PIT-tag vs. Freeze-brand Technology (Objective 5)}

We conducted linear analyses of the relationships between powerhouse flow and chinook salmon collection rates and compared collection efficiency for fish groups marked with passiveintegrated-transponder tags (PIT tags) versus those marked in earlier studies with freeze-brands. Results indicated that more precise collection efficiency estimates can be obtained with PIT-tag technology. The linear correlation between flow and collection efficiency was $r=0.829$ for PIT-tagged versus $r=$ 0.643 for freeze-branded fish (Fig. 2).

\section{Delayed Mortality Tests}

Mortalities from each of the delayed mortality tests and from the 24 hour holding periods prior to release are presented in Table 6 . 
Table 5.--Collection site, test number, median release-to-detection travel time, number of chinook salmon or steelhead released at Port Kelly, Washington, percent of the river flow passing through the powerhouse, proportion of the release recaptured at McNary Dam, and Chi-square level of significance (P) for tests to determine the effects of previous guidance experience on McNary Dam detection rates (Objective 4).

\begin{tabular}{|c|c|c|c|c|c|c|}
\hline $\begin{array}{c}\text { Collection } \\
\text { site }\end{array}$ & $\begin{array}{l}\text { Test } \\
\text { number }\end{array}$ & $\begin{array}{l}\text { Travel time } \\
\text { median }(\mathrm{h})\end{array}$ & $\begin{array}{l}\text { Number } \\
\text { released }\end{array}$ & $\begin{array}{l}\text { Powerhouse } \\
\text { flow (\%) }\end{array}$ & $\begin{array}{l}\text { Proportion } \\
\text { detected }\end{array}$ & $\begin{array}{c}\text { Chi-square } \\
\text { P }\end{array}$ \\
\hline \multicolumn{7}{|c|}{ Chinook salmon } \\
\hline $\begin{array}{l}\text { Bypass system } \\
\text { Forebay }\end{array}$ & 1 & $\begin{array}{l}37.0 \\
36.1\end{array}$ & $\begin{array}{l}617 \\
557\end{array}$ & $\begin{array}{l}93.5 \\
93.7\end{array}$ & $\begin{array}{l}0.65 \\
0.62\end{array}$ & 0.276 \\
\hline $\begin{array}{l}\text { Bypass system } \\
\text { Forebay }\end{array}$ & 2 & $\begin{array}{l}42.9 \\
38.9\end{array}$ & $\begin{array}{l}599 \\
375\end{array}$ & $\begin{array}{l}81.7 \\
80.5\end{array}$ & $\begin{array}{l}0.51 \\
0.47\end{array}$ & 0.272 \\
\hline $\begin{array}{l}\text { Bypass system } \\
\text { Forebay }\end{array}$ & 3 & $\begin{array}{l}32.8 \\
28.8\end{array}$ & $\begin{array}{l}599 \\
232\end{array}$ & $\begin{array}{l}87.7 \\
87.6\end{array}$ & $\begin{array}{l}0.69 \\
0.60\end{array}$ & $0.004 *$ \\
\hline \multicolumn{7}{|c|}{ Steelhead } \\
\hline $\begin{array}{l}\text { Bypass system } \\
\text { Forebay }\end{array}$ & 1 & $\begin{array}{l}38.0 \\
34.0\end{array}$ & $\begin{array}{l}580 \\
612\end{array}$ & $\begin{array}{l}100 \\
100\end{array}$ & $\begin{array}{l}0.74 \\
0.67\end{array}$ & $0.004 "$ \\
\hline $\begin{array}{l}\text { Bypass system } \\
\text { Forebay }\end{array}$ & 2 & $\begin{array}{l}66.0 \\
59.0\end{array}$ & $\begin{array}{l}586 \\
538\end{array}$ & $\begin{array}{l}100 \\
100\end{array}$ & $\begin{array}{l}0.64 \\
0.55\end{array}$ & $0.000 *$ \\
\hline
\end{tabular}

*Significant difference, $P<0.05$. 


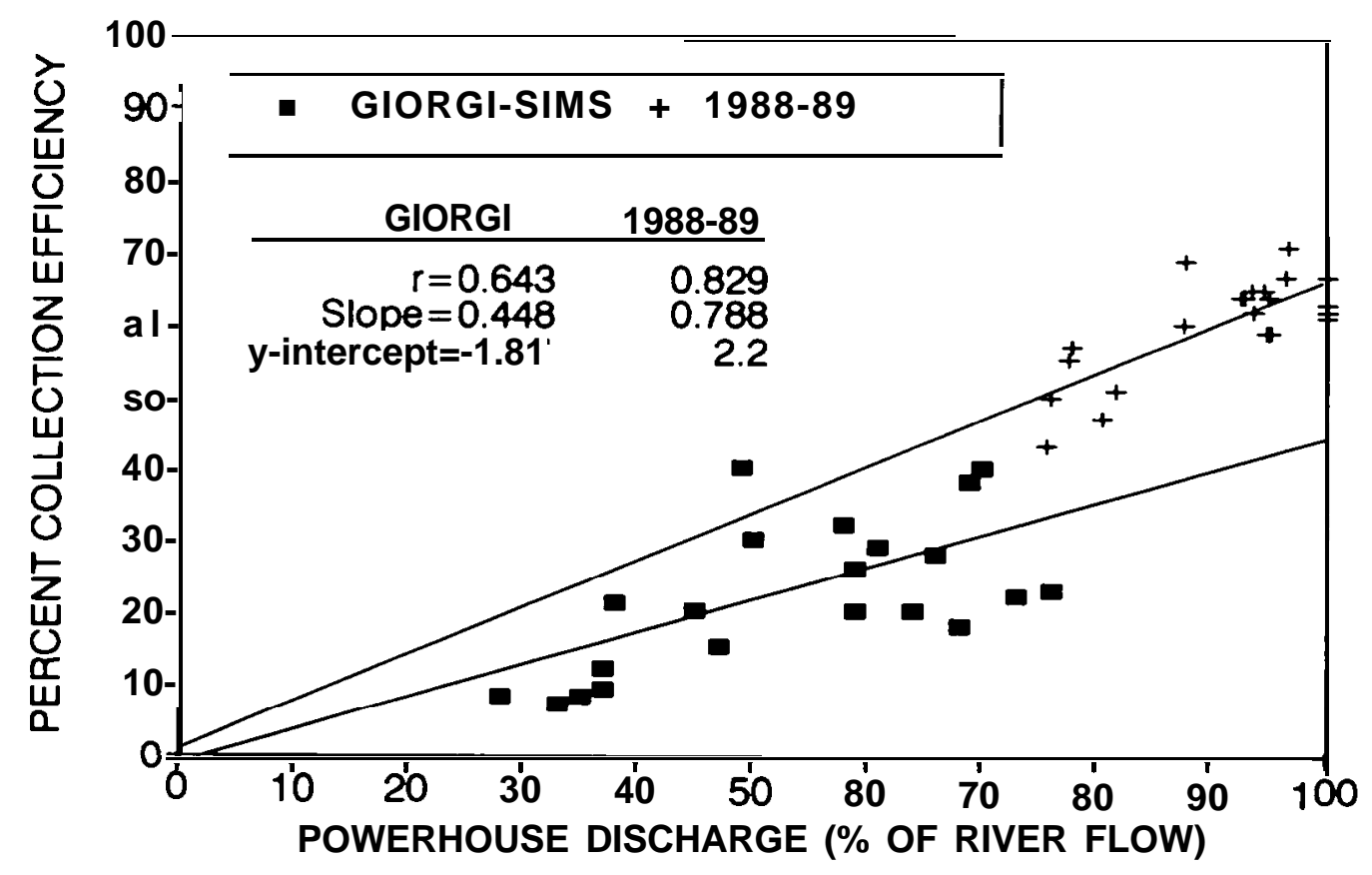

Figure 2.--Collection rates of release groups from freeze-brand (Giorgi-Sims) and PIT-tag studies at McNary Dam. 
Table 6.--Mortality during 4-day delayed mortality tests and during the 24-hour holding periods for the 1989 collection efficiency study.

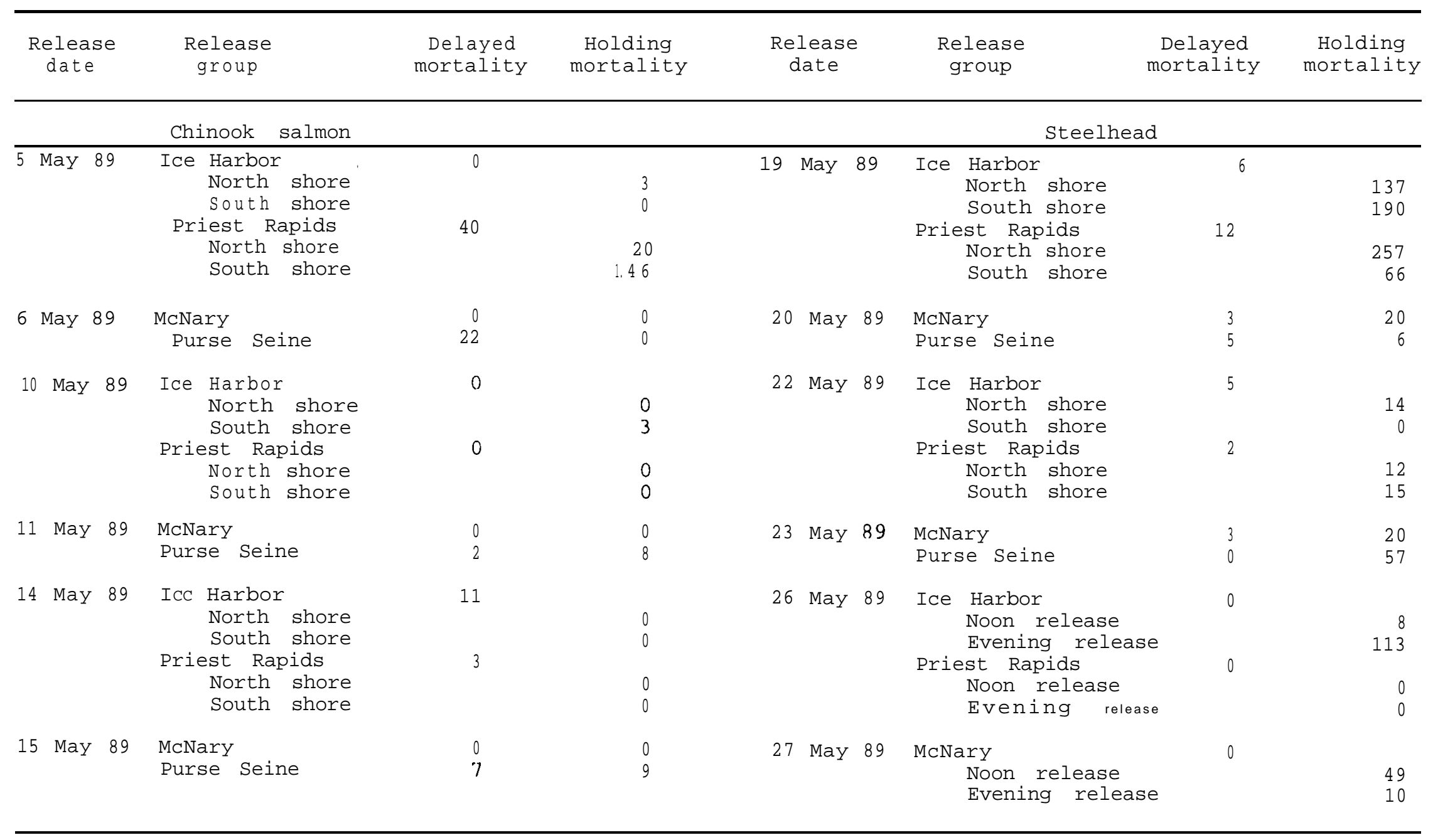




\section{DISCUSSION}

Differences in fish behavior, from the point that they were captured for tagging to their detection at McNary Dam, may have been associated with collection or handling techniques, reservoir migration, diel dam passage, and possibly fish guidance efficiency (FGE) - Any or all of these differences may have affected detection rates.

The standard handling procedure for juvenile salmonids at the Columbia River System dams is water-to-water transfer of test fish and use of a preanesthetic before tagging. However, during the 2 years of this evaluation of McNary Dam collection efficiency (1988 and 1989), test fish were obtained using 4 different handling methods: with and without water-to-water transfers and with and without preanesthetic. Significant detection differences may have occurred as a result of these different handling methods.

In 1988 (Stuehrenberg and johnson 1990), water-to-water methods were not used to remove fish from the purse seine and a preanesthetic was not used. Significant differences in detection were determined between purse seine and McNary Dam fish. In 1989, with fish collected by water-to-water transfer from the purse seine and treated with a preanesthetic, detection differences were not found during the first two chinook salmon tests. However, the detection rate for purse-seined fish was always lower (1988 and 1989) than that of fish obtained from the 
McNary Dam Juvenile Handling Facility and the effect of different capture methods could not be further evaluated.

The effects of release-to-detection mortality could not be directly evaluated. However, differences in collection efficiency rates were observed when there were delayed mortality differences between groups. Those groups with high rates of delayed mortality also had lower collection efficiency rates. However, the effects of release-to-detection mortality could not be separated from the effects of previous guidance at the collection site and differences in handling method.

Close similarity in release-to-detection travel time between purse-seined fish and those collected from the McNary Dam facility indicated that both groups were probably exposed to similar spill rates at the dam. Therefore, we ruled out the possibility that dam arrival time affected the detection difference determined from the third chinook salmon test. Information from the release-location tests suggested that fish approaching McNary Dam from south and north shore release sites were well mixed when powerhouse flow rates were > 90\%. At powerhouse flow rates between 80 and $90 \%$, there was inconclusive evidence of mixing. Me believe that north and south shore releases were not mixed when they arrived at McNary Dam during powerhouse flow rates between 75 and 80\% because Snake River fish from the second north shore release (spill side) had a significantly lower detection rate than those from the south shore release. 
In 1989, differences in release-to-detection travel time during the river-of-origin tests apparently influenced detection rates. Based on travel time, fish arriving at McNary Dam during different times of the day would be exposed to different flow proportions at the powerhouse and spillway. Those exposed to the higher spill rates would have lower detection rates. In addition, fish that arrived at the dam during peak passage hours (sunset to midnight) would have collection efficiencies that were directly correlated with the proportion of flow through the powerhouse. Fish that arrived during non-peak hours apparently mixed in the forebay until the next peak passage time. Fish collection efficiencies for these fish would be dependent on their forebay location when the next peak passage hours following their arrival occurred. During their forebay milling period these fish also likely experienced increased predation rates. However, because the period between gatewell entry and arrival at the monitors was unknown, this relationship could not be evaluated.

Differences detected during the river-of-origin tests (Table 3) provided the strongest evidence of an effect of travel time on detection rates. Snake River fish consistently arrived at MCNary Dam PIT-tag monitors 16 to 20 hours ahead of Columbia River fish. During the first test, Snake River fish, which apparently arrived during peak passage hours, had a significantly higher detection rate, but during the second test they had a significantly lower detection rate than Columbia River fish. 
Based on the PIT-tag detection times, the group exposed to the higher average release-to-detection spill rate had the lowest detection rate. It is noteworthy that in 1988, with the same difference in travel times between Columbia River and Snake River fish, but with no spill, detection rates were not significantly different. 


\section{CONCLUSIONS}

Based upon the 1988 and 1989 collection efficiency studies, and on comparative analysis of our results with those of previous studies, we arrived at the following conclusions:

i) Mixing of fish occurs between Port Kelley, Washington and McNary Dam at average release-to-detection powerhouse flow rates greater than 90 percent of the total river flow. At powerhouse flow rates less than 80 percent, mixing results were inconclusive.

2) River-of-origin does not directly affect detection rates (i.e. FGE is the same), however, differences between group travel time from release to detection will produce different detection rates when diel behavior and powerhouse and spill rates change.

3) Similarly, diel release time does not directly change collection rates (i.e. FGE is the same); however, differences between group arrival times will change detection rates.

4) The effect of using smolts previously collected from the collection system being evaluated could not be separated from the effect of using smolts obtained by different capture methods (handling stress and release-to-detection mortality differences).

5) PIT-tag technology produces higher and more accurate estimates of collection efficiency than freeze-brand technology 
6) Fish condition, resulting from handling technique and condition of the general population, will significantly affect detection rates by affecting release-to-detection mortality.

7) Under fluctuating powerhouse and spillway flow rates and with the possibility of redistribution of release groups in the forebay, any factor that changes arrival time at McNary Dam has the potential for changing collection efficiency estimation. Factors noted in this study were: diel release time and river-of-origin. 


\section{ACKNOWLEDGMENTS}

Support for this research came from the region's electrical ratepayers through the Bonneville Power Administration.

The following staff members of the National Marine Fisheries Service, Coastal Zone and Estuarine Studies Division, participated directly in the study: Stephen Achord, Scott McCutcheon, David Miller, William Ryan, and Dennis Umphfres.

The help and cooperation of personnel of the U.S. Army Corps of Engineers and Grant County Public Utility District were appreciated. 
LITERATURE CITED

Giorgi, A. E., and C. W. Sims. 1987. Estimating the daily passage of juvenile salmonids at McNary Dam on the Columbia River. N. Am. J. Fish. Manage. 7:215-222.

Prentice, E. F., T. A. Flagg, C. S. McCutcheon, D. F. Brastow, and D. C. Cross. 1990. Equipment, methods, and automated data-entry station for pit tagging. Am. Fish. Soc. Symp. $7: 335-340$.

Prentice, E. F., T. A. Flagg, C. S. McCutcheon, and D. F. Brastow. 1990. PIT-tag monitoring systems for hydroelectric dams and fish hatcheries. Am. Fish. Soc. Symp. $7: 323-334$.

Stuehrenberg, L. C., 0. W. Johnson. 1990. Evaluation of factors affecting collection efficiency estimates of chinook salmon and steelhead smolts at McNary Dam. Report to Bonneville Power Administration, Contract DE-AI79-88BP91024, 30 P (Available from Bonneville Power Administration, Division of Fish and Wildlife -PJ, P.0. Box 3621, Portland, OR 97208.) 